\title{
Specific control mechanisms for the Russian railway construction in the reign of Alexander III
}

\author{
Inna Barykina $^{1 *}$ \\ ${ }^{1}$ St. Petersburg Academy of In-Service Pedagogical Education, St. Petersburg, Russia
}

\begin{abstract}
The article covers the issues of the Russian railway development as part of the supply chain. The author discusses management process specific features in respect of the Northern Railway network construction and historical aspects concerning the Russian Empire during the reign of Alexander III. Solution to this problem was to develop specific (extraordinary) mechanisms of public governance. They included a special Institute of the Commission of experts and a special form of legislative acts called the all-Merciful manifestos. The study revealed disadvantages of such autocratic governing practice for railway construction and proved inefficiency of this approach to develop controlling mechanisms.
\end{abstract}

\section{Introduction}

The nature and extent of the problems studied, relate the research of the issues of the Russian railway supply chain development to extraordinary mechanisms of autocratic power implemented into management practice. Autocrats had a wide variety of extraordinary management mechanisms, mostly administrative ones. Control mechanisms were represented in specific forms and special institutions. All of them were temporary, organized from time to time to address current problems of internal politics. Russian Empire needed clear development plans of the country for the second half of the 19th century. However, in the absence of the official government program, certain special institutions received the legislative activity right. Other extraordinary authorities and mechanisms were adapted to address urgent program tasks [1].

One of these tasks was the railway construction in the northern part of the Russian Empire. Russian Minister of Finance Witte described the process in his memoirs, covering the period from 1892 to 1903 [3, 391-403]. In 1894, on behalf of Emperor Alexander III, the Minister made a trip to the Barents sea coast, the Murmansk coast to study the possibility of building a port there in the all-year-round ice-free harbor. Explaining the monarch's interest in this issue, S. Yu. Witte puts forward several reasons. These included: Alexander III's participation in the affairs of the Murmansk shipping company, understanding the need to build a railway in the region to provide reliable supply food chain [3]. The visit of the Minister of Finance coincided with the time, when a specially created Commission started to discuss the need of a railway in the north of Russia.

\footnotetext{
${ }^{*}$ Corresponding author: ibarykina@ mail.ru
} 


\section{Methods}

The object of study contains relevant information on the study of controlling processes' specific features regarding railway construction in severe northern conditions. Methodological basis of the article includes both traditional and innovative approaches being currently used in the research of the governing mechanisms. These include: an institutional, functional, comparative historical and empirical method of data collection. The article is also built on the principles of objectivity and historical nature. The research uses a number of approaches aiming to study the issues of the Russian railway supply chain development as historical aspects in the Russian Empire during the reign of Alexander III.

The article is based on several types of sources. These are regulations and record keeping documents, memoirs and diaries of statesmen. Official publications include publications from the archives of the Russian National Library. The Collection of printed notes provides references (comparative reviews) to manifestos, decrees and decrees issued during the reign of Alexander I, Alexander II and Alexander III as well as Nikolas I and Nikolas II. These sources provide insight into government assistance measures for displaced people. Problems of modernization of public administration are reflected in the diaries and memoirs of the following statesmen: Minister of Internal Affairs P.A. Valuev, Minister of Finance and Prime Minister S. Yu. Witte, public figure N.A. Kachalov.

The Institute of expert commissions, which existed in government practice, was in demand and filled with representative elements in the reign of Alexander II and at the beginning of the reign of Alexander III. Starting from the sixteenth century, regulatory authorities start discussing the idea of so-called "competent persons" to be involved in addressing important state affairs. The "competent persons" were authorized to perform expert assessment without the right to take part in legislative process. In the second half of the 19th century government leaders began to actively include "competent persons" to the activities of commissions under various bodies, including the State Council. However, experts could only participate in the discussion of issues in the course of the work of the Commission. But attended the meetings of the State Council to briefly answer the questions of its members, or submit their conclusions to the State Council. This way of participation in addressing state issues could not be considered as representative.

Transformation projects of the second half of the 19th century differed by the constantly circulated idea of the need to include other "advisory boards" in the structure of the state apparatus. These "advisory boards" were to include not bureaucrats, but experts or representatives. Such commissions were most often organized under the State Council. But there were proposals to create the boards under the ministries as well. For example, F. V. Chizhov proposed to introduce representatives from merchants and manufacturers to the Council of the Ministry of Commerce; P. A. Valuev offered to invite large landowners to the Council of the Minister of state property.

In addition, starting from the mid-nineteenth century, the government began to actively apply the practice of inclusion of "competent persons" in the Commissions activity under various authorities. Here are the examples of such Commissions:

1) Commission to assist the provinces affected by crop failure in 1868 and 1891;

2) Tariff Commission of 1867-1868, Passport Commission of 1869-1874;

3) Agricultural Commission of 1872-1873;

4) Commission for the Railways Construction in the North of the Russian Empire in 1894.

The latter was logically associated with the activity of the Commission to assist the provinces affected by crop failure and famine in 1868. S. Yu. Witte recalled Alexander III pointing out to him that "during the times of famine in the North, the authorities faced many difficulties with hunger, and many people died merely because of the government's inability 
to deliver bread there" [3]. The Emperor knew this firsthand. During the reign of his father, he was head of a specially created Commission.

Grand Duke Alexander Alexandrovich chaired a Commission for assistance to the Northern provinces affected by the famine in the North of Russia in 1867-1868. This story is reflected in the memoirs of N. A. Kachalov, Chairman of the Novgorod provincial Zemstvo, an employee of the Commission [5].

The Commission was attended by officials of the Ministries of internal Affairs, Railways, Land Plots, State property. In addition, the Commission involved the St. Petersburg and Moscow provincial marshals of the nobility, the Moscow mayor, master sergeant of the St. Petersburg General Duma, the Arkhangelsk Governor, representatives of the Exchange Committee and merchants. N. A. Kachalov recalled that "many experts from starving areas were invited" [5].

The task of the commissions was to collect donations and purchase bread to help the hungry. Formally, the Commission was headed by adjutant general N.V. Zinoviev. Grand Duke Alexander Alexandrovich became an honorary Chairman. Patronage of the heir to the throne, according to the government, was to prevent "inappropriate" expenditure of collected donations.

The Commission was created bypassing the activities of the Minister of internal affairs, P.A. Valuev. He sought to avoid panic and prevent dissemination of information about hunger. Having this situation, the Minister was offended by the mistrust of the Imperial family (the idea of raising funds was born in the presence of the heir and Empress Maria Alexandrovna) [2]. It was the first important state commission for the crown prince, in which he not only participated, but was heading it. The funds received due to the activity of the Commission were transferred to Trustees who did not disclose the purpose of the procurement. The Commission continued its activity from February to August 1868. The funds collected were spent to the needs of the hungry to the last kopeck. By the end of summer 1868 , the consequences of crop failure were eliminated.

The activity to supply bread to the starving population revealed the difficulties of transporting food due to the lack of transportation routes. It turned out that the only way to prevent such a disaster in the future "as well as to properly develop the region" is the construction of a railway between the cities of Vologda and Arkhangelsk or between Volga and North Dvina rivers. A detailed study of the issue began only in 1894. A Commission of "competent persons, as well as representatives of the local administration, Zemstvo and city administrations or other local institutions" was convened at the Department of Railways of the Ministry of Railways [4]. In addition to the representatives of the Ministry of Railways, it included officials of the Ministries of Finance, Military, Marine, Agriculture and State Property, State Control. A representative of the Finnish Senate also took part in it. The range of invited experts was wide and consisted of 25 people.

There was a member of Engineering Council of the Ministry of Railways, the chief of works of the port of Arkhangelsk, Russian Consul in the city of Memel, Director of the Murmansk shipping company, Arkhangelsk and Vologda former governors, a member of the Society for the promotion of Russian industry and trade, head offices of the Department of manufacture and trade, the skipper of the Murmansk shipping company, representatives of the Zemstvo and the St. Petersburg City Duma, mayors of the cities of Vologda, Kazan and Arkhangelsk, merchants, and a timber merchant. Mikhail Kazi, Director of the Murmansk shipping company was accompanying S. Yu. Witte in his trip to the Murmansk coast [3]. Cherepovets mayor Ivan Andreevich Milyutin had already had experience of such work, he was a member of the Commission in 1868. (References (comparative review) of the manifestos, decrees and orders issued in the reign of Alexander I, II and III and Nikolaev I and II, RGIA (Russian State Historical Archive). The collection of printed notes. Printed note No. 6) 


\section{Results}

The study found that autocratic power was trying to solve complex government problems by means of administrative levers having a temporary, extraordinary character shown in Tab.1.

Table 1. Migration policy measures introduced by the all-Merciful Manifestos

\begin{tabular}{|c|c|c|}
\hline $\begin{array}{l}\text { Document } \\
\text { Issue Date }\end{array}$ & Name & Assistance measures \\
\hline $\begin{array}{l}\text { October } \\
28,1866\end{array}$ & $\begin{array}{l}\text { Manifesto on the } \\
\text { occasion of the marriage } \\
\text { of the heir to the throne, } \\
\text { Tsarevich Alexander } \\
\text { Alexandrovich }\end{array}$ & $\begin{array}{l}\text { Forgiveness of loans granted to: } \\
\text { 1) low-income nobles for resettlement on state-owned } \\
\text { lands in Samara and Tobolsk provinces } \\
\text { 2) sums issued to Siberian settlers for acquiring a } \\
\text { household in case of marriage with local settlers } \\
\text { 3) farmers from among the Jewish population, who } \\
\text { received funds from the special capital of the State } \\
\text { Treasury for assisting the Jewish population }\end{array}$ \\
\hline $\begin{array}{l}\text { February } \\
19,1880\end{array}$ & $\begin{array}{l}\text { Supreme Decree on the } \\
\text { Occasion of the } 25^{\text {th }} \\
\text { Anniversary of the } \\
\text { Reign of Alexander II }\end{array}$ & Forgiveness of loans taken by settlers in Siberia \\
\hline $\begin{array}{l}\text { May } 15 \\
1883\end{array}$ & $\begin{array}{l}\text { Coronation Manifesto of } \\
\text { Emperor Alexander III }\end{array}$ & $\begin{array}{l}\text { Forgiveness of debts on loans issued to: } \\
\text { 1) Siberian settlers, coachmen, becoming peasant } \\
\text { owners and settled in the Moscow, Novgorod, St. } \\
\text { Petersburg and Tver provinces, } \\
\text { 2) Former colonists of the Ekaterinoslav province, } \\
\text { Estonians who resettled to Crimea in } 1862-1866 \text {, } \\
\text { 3) Providing bigger plots of land to those who settled on } \\
\text { the Murmansk coast. }\end{array}$ \\
\hline
\end{tabular}

The right of pardon and mercy as a prerogative of the monarch was one of the manifestations of the essence of autocratic power. It was not by chance that it developed throughout the entire existence of the Russian Empire. All-Merciful Manifestos gave the leaders the opportunity to use some administrative relief, timing the highest mercy to coincide with the solemn events in the life of the state and the Royal family. In the second half of the nineteenth century this right has become an important tool in the mechanism of the reign of the autocrat. Publication of the all-Merciful Manifestos in the second half of the 19th century gave the autocrats the opportunity to adjust domestic policy on its individual items through the right of pardon and mercy without undertaking obligations to implement the government program. The absence of an approved government program led to the increased government practice to use acts of mercy more often. In the end of the 19th century, these acts covered almost all aspects of public life. The law that allowed the resettlement was not adopted in the reign of Alexander II. But the government was forced to constantly keep the resettlement issue in the area of immediate attention, especially since crop failure and famine contributed to spontaneous resettlement. Single steps in this direction were declared by manifestos. Manifesto of October 28, 1866 (on the occasion of the marriage of the heir Tsarevich Alexander Alexandrovich to the throne) forgave the loans granted to the poor nobles for resettlement to state lands in the Samara and Tobolsk province and the amounts issued to Siberian settlers for the establishment of a household in case of marriage with local settlements, as well as loans to farmers from the Jewish population, who received funds from the special capital of the state Treasury for the Jewish population. Decree of February 19th, 1880, (on the occasion of the 25th anniversary of the reign of Alexander II) announced forgiveness of loans in case of marriage with local settlers from Siberia. The coronation Manifesto of Alexander III in addition to Siberian settlers forgave debts on loans issued to 
coachmen who became peasant owners and settled in the Moscow, Novgorod, St. Petersburg and Tver provinces, former colonists of the Ekaterinoslav province, Estonians who moved to the Crimea in 1862-1866 [6]. The same act declared addition of arrears from those, who "accepted settlement on the Murmansk coast".

\section{Discussion}

Discussing the direction of future ways of communication with representatives of different departments in the Commission on Railway Construction in the North of Russia, it became clear that the Murmansk coast is scarcely populated. According to Arkhangelsk Governor A. P. Engelhardt there were 45 settlements with a permanent population on the coast: the town of Kola with its 740 people, and 44 colonies with a population of 2,021 people. There were 707 Finnish, 679 Russians, 454 Lopera and 188 Norwegians. The largest colonies were Ura, Pechenga and Zemlianaya. In addition to these settlements, there were also 12 camps on the Murmansk coast, the inhabitants of which lived there only in summer (from 3,000 to 4,000 natives of Kemsky and Onega counties engaged in fishing), increasing the population of the coast to 6,000 people [4]. There was a discussion about the cause of the situation and its consequences. Opinions divided: some insisted to first populate the coast, and build railways afterwards in this direction. Other members of the Commission argued that without a railway resettlement to that area is meaningless. Nevertheless, the government has sought a variety of ways to attract immigrants to the Murmansk coast. They included the reduction of the costs, which was declared in the all-Merciful Manifestos.

Issuing the all-Merciful Manifestos, the government tried to solve various domestic political problems. Without radical changes in the system of public administration and concessions in the field of government, the government leaders attempted to adjust domestic policy by all-Merciful Manifestos. But it was impossible to address key sociopolitical and economic problems only through the right of pardon and mercy.

Historians also drew attention to special, extraordinary institutions, the emergence of which was associated with emergency situations in public life. These institutions were temporary government systems created to address a particular domestic political problem. But it did not undermine the stability prevailing in the beginning of the 19th century. The study of this aspect of domestic policy at the example of the issue of railway construction, adds to our understanding of specific aspects of the autocratic control system.

\section{Conclusions}

Extraordinary mechanisms to address urgent problems resulted in temporary relief and did not remove them from the program objectives agenda. The evidence of it is drawn from the fact that the discussion of the issue of a railway in the North of the Russian Empire took a very long time, more than 30 years. Railway construction in this region started only in the next reign, under Nicholas II.

\section{References}

1. I.E. Barykina, Public administration of Russia in the second half of the nineteenth century (special forms and special institutions) (Petersburg, 2018).

2. P.A. Valuev, Minister of internal Affairs. 1861-1876, in 2 volumes, (Petersburg, 1961).

3. S.Yu. Witte, Memories, in 3 volumes, Volume 1, (Petersburg, 1960).

4. Journal of the Commission for Railways in the North of Russia, (Petersburg, 1894). 